\title{
509 せん断流れ場における in vitro 血栓形成挙動観察 \\ Observation of in vitro thrombosis behavior under shear flow field
}

\author{
○正 丸山 修 (産総研), 可児裕基（東理大院）, 小阪 亮（産総研）, 西田正浩（産総研）, \\ 山根隆志（産総研），巽 英介（国循），妙中義之（国循）
}

\begin{abstract}
In vitro antithrombogenic testing is a useful pre-evaluation for ex vivo test of a continuous flow pump as an artificial heart. In our previous study, we have quantitatively obtained the results that the increasing shear rate prevented the thrombus formation using a double-cylinder type rheometer. However, it is not yet cleared that the thrombosis procedures occurred at between the inner and the outer cylinders. This paper describes that the optical and direct observation of the in vitro thrombosis under shear flow fields. This results showed that the thrombus formation started from the surface of rotating outer cylinder made of glass. Thus, it is considered that in vitro thrombosis closely related to the not only blood coagulability and/or shear rate, but also chemical condition of blood-contacting surface.
\end{abstract}

Key Words: Hemolysis, Surface roughness, Shear stress, Thrombosis, Rheometer

\section{1. はじめに}

人工心臟や体外循環ポンプなどの循環器系人工臟器に使用する血 液ポンプは, ウィルヒョーの三原則に基づき, 血流のせん断速度, 血液凝固能，ポンプの血液接触材料の複合的要因によって，血液ポ ンプ内に血栓が生じ，合併症を引き起こすことが悬念される. 血液ポ ンプを設計するにあたり，血栓形成に対してこれら三者の要因の関 係を定量的に調べるこが，血栓防止の有効な指標になると考えて いる.我々は，これまでに，図1に示すような二重円筒型レオメータ （侏片ルクエスト製レオロジア A300）を利用して，試験血液の凝固 能とせん断速度に対する血栓形成度（血栓形成量）について調べてき た. このレオメータは，せん断負荷部が，ステンレス製の内筒および ガラス製の外筒からなる二重円筒式で, 外筒が回転するしくみである.
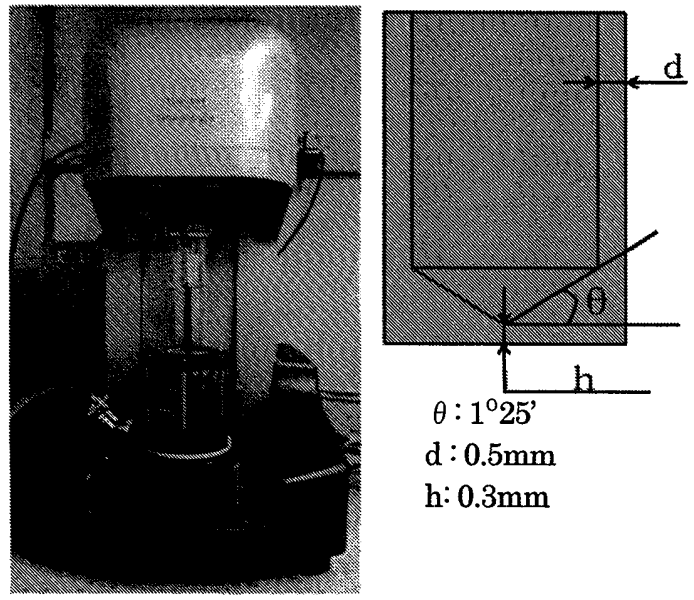

Fig.1 Observation and cross-section of the shearing portion of a double-cylinder type rheometer

その結果，活性化疑固時間（ACT）が低いほど，またせん断速度が 小さいほど血栓形成度は大きいこと，また，せん断負荷が同一でも， せん断速度の増加によって血栓形成が抑制できることが定量的に明 らかとなった．しかしながら，現状では，二重円筒からなる均一な せん断流れ場において，平均值として得られる血栓形成度を計測し
ただけであり，具体的にどのような過程を経て，血栓が形成するか については明らかにできていない，そこで，レオメータ内での血栓 形成挙動を観察することで，これまでに得られたせん断流れ場にお ける in vitro 血栓形成度について，さらに詳細な知見を得られるも のと考えている.

\section{2. 目的}

二重円筒型レオメータを使用して, 任意のせん断速度およびACT に 設定したウシ血液について，せん断負荷時間に伴って内筒および外 筒に付着・残存した血栓を光学的および直接観察し, 血栓形成度に伴 う挙動を観察することを目的とした。

\section{3. 実検方法}

使用したレオメータの内筒軸にはトルクセンサーが設置してある. 血液疑固によって粘性が増加し，内筒と外筒の間で血栓が形成する と, トルク值増加の経時変化が観察される. 2\%塩化カルシウムを添加 し，ACTを200 sに設定したウシ血液を内筒と外筒の隙間に4. $2 \mathrm{~mL}$ 充填

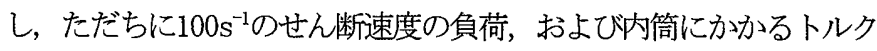
の計測を開始した. せん断負荷後, 血栓形成によって変化するトルク を, (I)トルク值が増加しない状態 (II) トルクが増加を始めた時, (III) トルクがピーク值をとる時, およびIV)トルクが減少していると きの4つの過程に分け，それぞれにおける血栓形成過程を次の二つの 方法により観察した. まず，レオメータのせん断負荷部に近赤外線を 照射し， $720 \mathrm{~nm}$ までの可視光を吸収カットする 赤外線フィルターIR72037mm)を取り付けたカムコーダ(ソニー(株), HDR-SR8)を使用して撮影した. なお，撮影はカムコーダの赤外線力 ットフィルターを使用しない機能を使用して行い, 輝度の変化から血 栓を観察した. また，せん断負荷部を分解し，内筒に形成した血栓を 直接観察した.

\section{4. 実騟結果}

実験方法で記述したトルク值が変化する領域である (I)〜 (IV) の 
過程は，せん断負荷時間として，それぞれ100s，220s，290sおよび 1,000sで得られることがわかった（図2）。

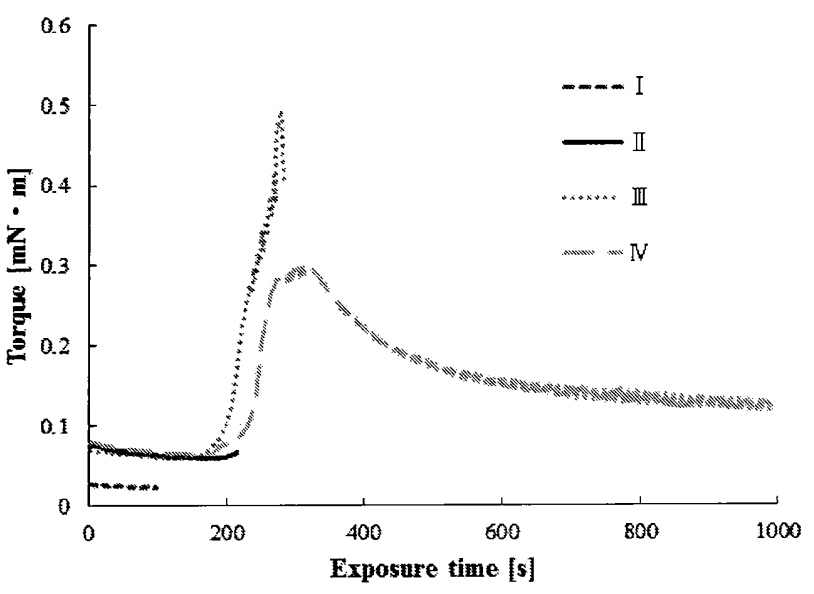

Fig.2 Torque values with 4 different exposure time for bovine blood with ACT of $200 \mathrm{~s}$ at shear rate of $100 \mathrm{~s}^{-1}$

せん断負荷中のカムコーダによる光学的観察と, せん断負荷後 の直接観察の結果を表 1 に示した.

Table1 Observation of in vitro thrombosis of bovine blood with ACT of $200 \mathrm{~s}$ at shear rate of $100 \mathrm{~s}^{-1}$ for $100,220,290$ and $1,000 \mathrm{~s}$. Observation (1) was obtained by a camcorder, and observation (2) was obtained by direct observation after disassembling of inner and outer cylinder.

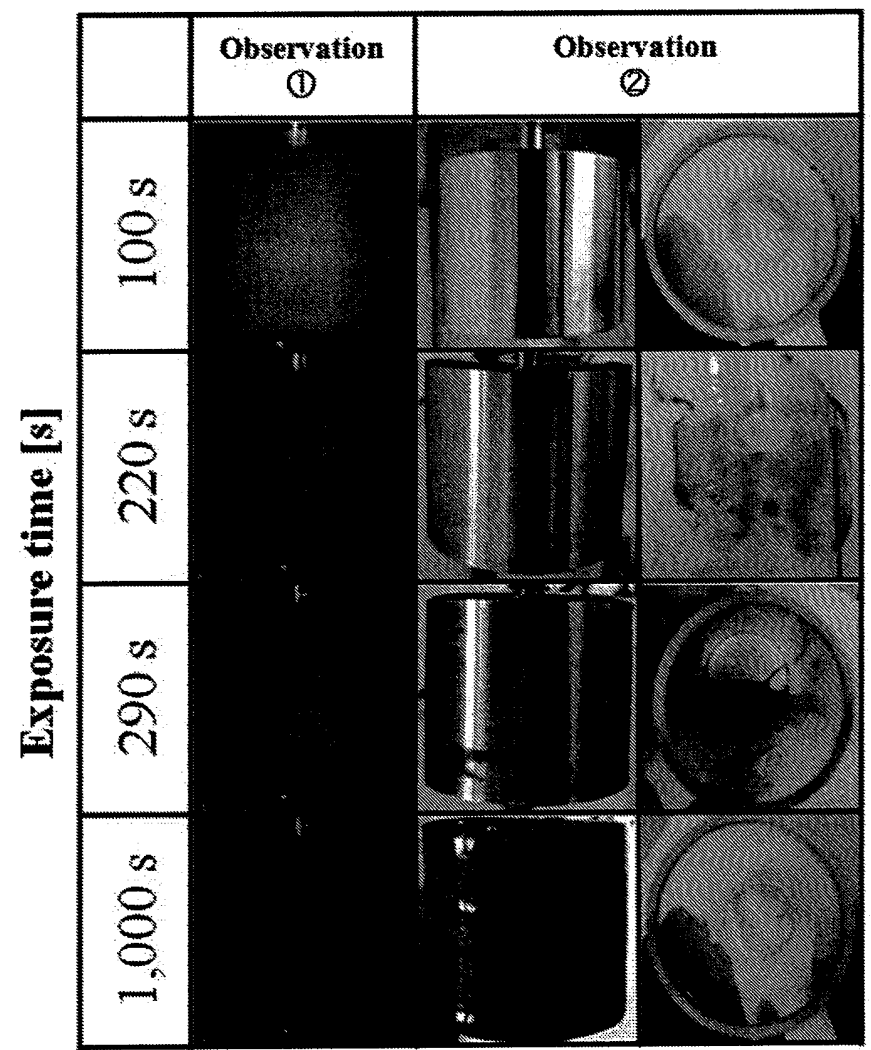

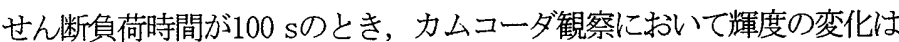
確認されず，また，直接観察においても血栓は確認されなかった，せ し断負荷時間が $220 \mathrm{~s}$ のき, カムコーダ観察において輝度が高い部分 が現れ，外筒の回転に追随した．また，直接観察において内筒には血 栓を確認できなかったが，外筒に薄い血栓の付着を確認した. せん断 負荷時間 $290 \mathrm{~s}$ のとき，カムコーダ観察において輝度の非常に高い点が 現れ，その点の下流側に輝度が高い線が形成され，輝度が高い部分は， 外筒の回転に追随した．次いで，外筒の回転によらず静止する高輝度 部分が現れた. この高輝度部分と一致する内筒箇所に血栓の付着を確 認した．せん断負荷時間1,000 sのとき，カムコーダ観察において輝度 が高い部分はすべて静止した。 また，直接観察では内筒に厚い血栓が 形成し，血液全量が血栓に転換したことを確認したが，外筒に血栓は 付着しなかった。

\section{5. 考察}

実験結果から，せん断負荷部である内筒と外筒の隙間において， 血栓は外筒表面から形成し始め，しばらく外筒とともに回転しなが ら外筒円周方向に血栓が成長，次いで半径方向の内筒に向かって血 栓形成が促進，最終的には血栓が内筒に付着し，外筒からは剥離す る挙動を示すことがわかった．静止壁である内筒からではなく，回 転壁である外筒から血栓形成が生じたことについては，次のように

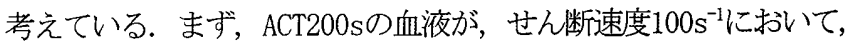
外筒表面のガラスと接触して内因系凝固反忘が促進寸る. 外筒表面 の円周方向に血栓形成が促進した後，内筒側の半径方向に成長を始 める．血栓形成に伴って内筒と外筒の陌間が狭くなることでせん断 応力が増加して血小板が活性化し，やがてこの活性化した血小板が 内筒と粘着したのちに，血栓が外筒から剥離するものと考えている. しかし，本実験結果は，内筒と外筒が異なる材質であり，同一材料 であればこの血栓形成挙動も異なる可能性がある. 今後, この考察 を立証するために，血液凝固因子濃度および血小板活性を計測する とともに，表面材料がin vitro血栓形成挙動に与える知見を得る必 要がある.

\section{6. 結論}

せん断流れ場におけるin vitro血栓形成に関しては，血液凝固能 やせん断速度だけでなく，血液接触材料の影響が考えられた。

\section{哨辞}

本研究は, NEDO再委託「小柄患者用補助人工心臓の有効性および安 全性の評価」により行われたものであり，謝意を表する。

\section{孝文献}

1）丸山ら，第21回茨城講演会講演論文集，pp151-152（2014.9） 